\title{
Analisis Kekuatan Struktur Bangunan Dermaga Kayu di Babo Teluk Bintuni, Papua Barat
}

\section{(Analysis of the Structural Strength of a Wooden Pier in Babo Teluk Bintuni, West Papua)}

\author{
Adan Kamarudin ${ }^{1 *}$ dan Erizal ${ }^{1}$ \\ ${ }^{1}$ Departemen Teknik Sipil dan Lingkungan, Fakultas Teknologi Pertanian, Institut Pertanian Bogor. \\ Jl. Raya Dramaga, Kampus IPB Dramaga, PO BOX 220, Bogor, Jawa Barat, Indonesia \\ *Penulis Korespondensi: adankamarudin@gmail.com
}

Diterima: 25 Maret 2021

Disetujui: 20 Juli 2021

\begin{abstract}
Analysis of structural strength to the conditions of the jetty Port Babo of Teluk Bintuni, West Papua is important to ensure the stability of the against external loads and forces. The purpose of this research is to analyse and evaluate the strength of structures, as well as assess the durability of jetty structures. Modeling using the SAP2000 program corresponds to as built drawing. The results of the calculation of the working load include dead loads, live loads, ship berth, ship mooring force, current force, wave force, and earthquake force. Energy due to ship collision loads and vessel berthing force can be reduced using a fender designed using rubber fenders seibu V30OH. The results of the structural analysis show that the number of combined variants is sufficient up to the shape mode 12. The dynamic earthquake shear forces in the $x$ and $y$ directions are still smaller than the static shear forces, so it needs to be multiplied by a scale factor of 2,9. The deviation that occurs in the structure is still smaller than the allowable deviation of 350 $\mathrm{mm}$. Beams are designed using reinforcement with diameter $22 \mathrm{~mm}$ and $25 \mathrm{~mm}$. The stress ratio value at the pile meets the pile capacity. It can be said that overall the Babo Teluk Bintuni wharf is safe from the working load.
\end{abstract}

Keywords: Jetty, Modeling, SAP 2000, Structural Analysis.

\section{PENDAHULUAN}

Pelayaran antar pulau di Indonesia merupakan salah satu sarana transportasi dan komunikasi yang dapat diandalkan dalam mewujudkan pembangunan nasional yang berwawasan Nusantara. Pelayaran sebagai sarana transportasi antar pulau mampu menyeimbangkan perdagangan dan meningkatkan mobilitas penduduk dari satu pulau ke pulau lainnya, sedangkan fungsinya sebagai sarana komunikasi memungkinkan berlangsungnya pertukaran sosial budaya antar berbagai suku dan memungkinkan terselenggaranya hubungan pemerintah pusat dan daerah. Hal tersebut tidaklah mengherankan karena Indonesia merupakan negara kepulauan terbesar di dunia yang menempati jalur silang strategis yaitu Samudera Hindia dan Samudera Pasifik.

Pulau yang paling jauh dari pusat pemerintahan di Indonesia adalah pulau Papua, yang terbagi menjadi dua provinsi, yaitu Provinsi Papua dan Papua Barat. Jalur angkutan laut menjadi pilihan utama bagi masyarakat Papua dibandingkan dengan jalur angkutan udara atau angkutan darat dikarenakan daerah yang bergunung-gunung dan transportasi udara yang cenderung lebih mahal. Penggunaan jalur angkutan laut dalam mengembangkan komoditas kelautan membutuhkan prasarana, 
seperti pelabuhan dan prasarana transportasi, sehingga komoditas yang dihasilkan dapat menjangkau pasar.

Pelabuhan mempunyai peran penting bagi perekonomian sehingga tuntutan akan jasa pelabuhan semakin meningkat. Pelabuhan di Teluk Bintuni menjadi salah satu kawasan andalan laut yang terletak di Provinsi Papua Barat yang mengandalkan penggunaan jalur angkutan laut sebagai pendukung pengembangan perikanan dan gas alam. Pasal 1 ayat 23 Undang-Undang Perikanan, Departemen Kelautan dan Perikanan (DepKP 2004) menyebut Pelabuhan Perikanan merupakan tempat kegiatan pemerintahan dan kegiatan sistem bisnis perikanan yang digunakan sebagai tempat kapal perikanan bersandar, berlabuh, atau bongkar muat ikan yang dilengkapi dengan fasilitas keselamatan. Selain perikanan, Pelabuhan Bintuni digunakan sebagai dermaga untuk muat (loading) gas alam berupa liquefied natural gas (LNG).

Babo merupakan salah satu distrik di Kabupaten Teluk Bintuni, Papua Barat yang memiliki dermaga kayu (jetty) yang menjadi tempat transit kapal dari Sorong menuju Bintuni ataupun sebaliknya. Bangunan jetty tersebut dibuat dari jenis kayu terseleksi yang dianggap memiliki kekuatan yang tinggi dengan keawetan terhadap serangan organisme perusak yang baik (marine borer). Kayu yang memiliki kekuatan dan keawetan yang baik adalah kayu dengan kerapatan kayu tinggi dan kandungan ekstraktif yang memadai. Adanya faktor lingkungan dan waktu serta penerimaan beban secara menerus akibat pemakaian dan faktor pemeliharaan menyebabkan bangunan tersebut dapat mengalami deteriorasi. Analisis mengenai kekuatan struktur terhadap kondisi dermaga kayu atau jetty tersebut penting dilakukan karena menyangkut keamanan dan kenyamanan pengguna. Selain itu, kekuatan struktur harus diperhitungkan untuk dapat menjamin kestabilan bangunan terhadap beratnya sendiri, beban-beban bangunan (beban isi bangunan), gaya-gaya luar yang bekerja seperti gempa bumi, tekanan angin, dan lain-lain tanpa harus mengalami perubahan yang melebihi batas yang diijinkan (Nusantara 2014).

\section{METODOLOGI}

Penelitian "Analisis Kekuatan Struktur Bangunan Dermaga Kayu di Babo Teluk Bintuni, Papua Barat" dilakukan dari bulan April hingga Juli 2020. Penelitian dilaksanakan di Babo Teluk Bintuni, Papua Barat. Secara geografis Pelabuhan Babo Teluk Bintuni terletak pada $2^{\circ} 32^{\prime} 2,07^{\prime \prime}$ LS dan $133^{\circ}$ $27^{\prime}$ 7,57' BT. Lokasi penelitian disajikan pada Gambar 1.

Penelitian dilakukan dalam beberapa tahapan yaitu pengumpulan data sekunder, studi pustaka, pengolahan data dan penyusunan laporan. Peralatan yang digunakan adalah seperangkat komputer yang dilengkapi dengan perangkat lunak Microsoft office, AutoCAD, dan SAP 2000. Bahan yang digunakan dalam penelitian ini antara lain data sekunder berupa as built drawing jetty Babo, Peta Gempa Indonesia 2010, peraturan SNI, perhitungan pembebanan struktur jetty berdasarkan panduan The Overseas Coastal Area Development Institute Of Japan (OCDI 2002).

Data yang diperlukan dalam analisis struktur dermaga jetty untuk mendapatkan karakteristik kekuatan pada struktur seperti data arus dan pasang surut, data kapal, data angin dan gelombang, data tanah, serta data dermaga. Pemodelan struktur dibuat dengan menggunakan program SAP2000 dengan data utama yang digunakan yaitu as built drawing. Hasil pemodelan yang didapatkan yaitu bentuk 
model struktur secara tiga dimensi. Pemodelan struktur dikondisikan dengan keadaan struktur sebenarnya.

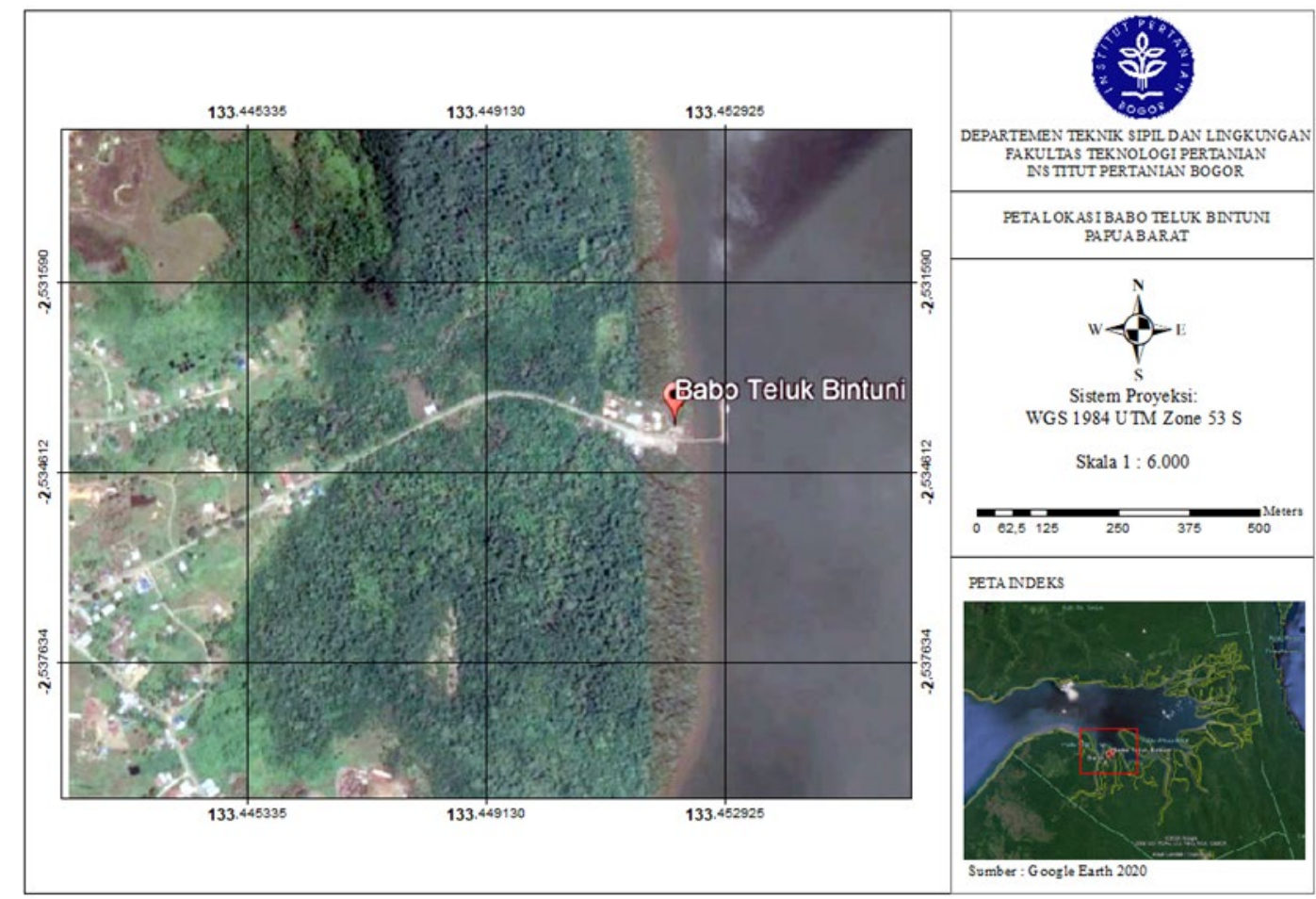

Gambar 1 Peta Lokasi Penelitian

Analisa struktur dermaga terdiri dari syarat teknis perencanaan seperti data bahan, data perencanaan, jenis-jenis beban yang bekerja pada struktur serta kombinasi beban. Kontrol kelangsingan balok kemudian dihitung berdasarkan peraturan SNI. Beban-beban yang bekerja meliputi beban horisontal dan vertikal dihitung. Beban vertikal meliputi beban mati dan beban hidup, sedangkan beban horisontal terdiri dari beban gelombang, beban arus, beban gempa, beban benturan kapal, dan gaya tambat. Hasil perhitungan pembebanan dikombinasikan melalui persamaan berdasarkan panduan Port Of Long Beach (POLB 2012).

Beban gelombang terdiri dari beban gelombang pada struktur tiang dan beban gelombang pada tepi dermaga. Perhitungan beban gelombang pada struktur tiang menggunakan persamaan berikut.
$F_{x}=F_{d m a x}|\cos \omega t| \cos \omega t-F_{i \max } \sin \omega t \ldots(1)$

$\mathrm{F}_{\mathrm{dmax}}=\frac{1}{16} \rho \mathrm{g} \mathrm{C}_{\mathrm{d}} \mathrm{DH}^{2} \frac{\sinh (2 k h)+2 k h}{\sinh (2 k h)} \ldots$

$\mathrm{F}_{\mathrm{imax}}=\frac{\pi}{8} \rho \mathrm{g} \mathrm{C}_{\mathrm{m}} \mathrm{D}^{2} \mathrm{H} \tanh (\mathrm{kh})$

Keterangan :

$\mathrm{F}_{\mathrm{x}} \quad=$ gaya total pada $\operatorname{arah} \mathrm{x}(\mathrm{N})$

$\mathrm{F}_{\mathrm{dmax}}=$ gaya drag maksimum $(\mathrm{N})$

$\mathrm{F}_{\mathrm{i} \text { max }}=$ gaya inersia maksimum $(\mathrm{N})$

$\rho=$ berat jenis air laut $\left(=1025 \mathrm{~kg} / \mathrm{m}^{3}\right)$

$\mathrm{g}=$ percepatan gravitasi $\left(\mathrm{m} / \mathrm{s}^{2}\right)$

$\mathrm{D}=$ diameter tiang pancang $(\mathrm{m})$

$\mathrm{H}=$ tinggi gelombang $(\mathrm{m})$

$\mathrm{h}=$ tinggi muka air $(\mathrm{m})$

$\mathrm{k}=$ bilangan gelombang $\left(\frac{2 \pi}{L}\right)$

$\mathrm{L}$ = panjang gelombang $(\mathrm{m})$

$\mathrm{C}_{\mathrm{d}}=$ koefisien drag

$\mathrm{C}_{\mathrm{m}}=$ koefisien inersia

$\omega=$ frekuensi gelombang $\left(\frac{2 \pi}{T}\right)(\mathrm{Hz})$ 
$\mathrm{T}=$ Periode gelombang (detik)

$\mathrm{t}=$ waktu (detik)

Ada kemungkinan tinggi gelombang mencapai elevasi dermaga, sehingga perlu diperhitungkan gaya gelombang terhadap tepi dermaga. Perhitungannya dapat menggunakan persamaan berikut.

$\mathrm{P}=\frac{\rho g H}{2 k \cosh k h}[(\operatorname{sink}(\mathrm{h}+\mathrm{s}+\mathrm{t})-\sin \mathrm{k}(\mathrm{h}+\mathrm{s}))] \ldots$

Keterangan :

$\mathrm{P}=$ gaya gelombang pada tepi $(\mathrm{N} / \mathrm{m})$

$\rho=$ berat jenis air laut $\left(=1025 \mathrm{~kg} / \mathrm{m}^{3}\right)$

$\mathrm{g}=$ percepatan gravitasi $\left(\mathrm{m} / \mathrm{s}^{2}\right)$

$\mathrm{h}=$ kedalaman air laut $(\mathrm{m})$

$\mathrm{H}=$ tinggi gelombang $(\mathrm{m})$

$\mathrm{k}=$ bilangan gelombang $\left(\frac{2 \pi}{\mathrm{L}}\right)$

$\mathrm{L}=$ panjang gelombang $(\mathrm{m})$

$\mathrm{S}=$ elevasi HWS (m)

$\mathrm{t}=$ tebal pelat dermaga $(\mathrm{m})$

Beban arus terdiri dari drag force dan lift force. Beban ini disebabkan oleh perilaku arus yang dihitung melalui persamaan OCDI berikut.

$\mathrm{F}_{\mathrm{D}}=1 / 2 \mathrm{C}_{\mathrm{D}} \rho_{0} \mathrm{~A} \mathrm{U}^{2}$

$F_{L}=1 / 2 C_{L} \rho_{0} A U^{2}$

Keterangan :

$\mathrm{F}_{\mathrm{D}}$ = gaya drag akibat arus $(\mathrm{kN})$

$\mathrm{F}_{\mathrm{L}}=$ gaya angkat akibat arus $(\mathrm{kN})$

$\mathrm{A}=$ luas penampang kena arus $\left(\mathrm{m}^{2}\right)$

$\mathrm{U}=$ kecepatan arus $\left(\mathrm{m} / \mathrm{s}^{2}\right)$

$\rho=$ berat jenis air laut $\left(=1,03 \mathrm{t} / \mathrm{m}^{3}\right)$

$\mathrm{C}_{\mathrm{D}}=$ koefisien drag

$\mathrm{C}_{\mathrm{L}}=$ koefisien lift

Pembuatan grafik respon spektrum gempa rencana dilakukan berdasarkan SNI 1726-2012 (BSN 2012). Nilai spektrum dipengaruhi oleh periode getar, rasio redaman, tingkat daktalitas, dan jenis tanah.
Gaya tumbukan kapal adalah gaya yang diterima dermaga saat kapal sedang bersandar pada dermaga. Gaya maksimum yang diterima dermaga adalah saat kapal merapat ke dermaga membentur dermaga pada sudut $10^{\circ}$ terhadap sisi depan dermaga. Gaya benturan diterima dermaga dan energinya diserap oleh fender pada dermaga. Besar energi tersebut dihitung menggunaka persamaan OCDI berikut.

$\mathrm{E}_{\mathrm{f}}=\frac{M_{s} V^{2}}{2} \mathrm{C}_{\mathrm{e}} \mathrm{C}_{\mathrm{m}} \mathrm{C}_{\mathrm{s}} \mathrm{C}_{\mathrm{c}}$

$\mathrm{F}_{\text {berthing }}=\frac{M_{S} V}{\Delta t}$

Keterangan :

$\mathrm{E}_{\mathrm{f}}=$ energi tumbukan kapal $(\mathrm{kNm})$

$\mathrm{M}_{\mathrm{s}}=$ massa air yang dipindahkan (ton)

$\mathrm{V}=$ kecepatan kapal saat membentur dermaga $(\mathrm{m} / \mathrm{s})$

$\mathrm{C}_{\mathrm{e}}=$ koefisien eksentrisitas

$\mathrm{C}_{\mathrm{m}}=$ koefisien massa semu

$\mathrm{C}_{\mathrm{s}}=$ koefisien kekerasan

$\mathrm{C}_{\mathrm{c}}=$ koefisien konfigurasi penambatan

$\mathrm{F}_{\text {berthing }}=$ gaya tumbukan kapal $(\mathrm{kN})$

$\Delta \mathrm{t}=$ waktu kapal membentur dermaga (detik)

Gaya tambat kapal yang dihitung berdasarkan arah angin datang yaitu arah haluan, arah buritan, dan arah lebar kapal. Persamaan yang digunakan untuk menghitung gaya tambat melalui persamaan berikut.

Arah haluan $\left(\alpha=0^{\circ}\right)$

$\mathrm{Rw}=0,42 \mathrm{Q}_{\mathrm{a}} \mathrm{A}_{\mathrm{w}}$

$\mathrm{Q}_{\mathrm{a}}=0,063 \mathrm{~V}_{\mathrm{w}}^{2}$

Arah buritan $\left(\alpha=180^{\circ}\right)$

$\mathrm{Rw}=0,5 \mathrm{Q}_{\mathrm{a}} \mathrm{A}$

$\mathrm{Q}_{\mathrm{a}}=70 \% \mathrm{~B} D$ 
Arah lebar kapal $\left(\alpha=90^{\circ}\right)$

$\mathrm{Rw}=1,1 \mathrm{Q}_{\mathrm{a}} \mathrm{A}$

$\mathrm{Q}_{\mathrm{a}}=70 \%$ Loa $\mathrm{D}$

Keterangan:

$\mathrm{R}_{\mathrm{W}}$ = gaya akibat angin $(\mathrm{Kg})$

$\mathrm{Q}_{\mathrm{a}}=$ tekanan $\operatorname{angin}\left(\mathrm{Kg} / \mathrm{m}^{2}\right)$

$\mathrm{V}_{\mathrm{w}}=$ kecepatan angin $(\mathrm{m} / \mathrm{det})$

$\mathrm{A}_{\mathrm{w}}=$ proyeksi bidang tertiup angin $\left(\mathrm{m}^{2}\right)$

Loa $=$ panjang $\operatorname{kapal}(\mathrm{m})$

$\mathrm{B}=$ kedalaman $\operatorname{kapal}(\mathrm{m})$

$\mathrm{D}=$ drift $\operatorname{kapal}(\mathrm{m})$

Beban beban yang telah dianalisis kemudian dikombinasikan melalui persamaan pada Tabel 1 .

Tabel 1 Kombinasi Pembebanan

\begin{tabular}{cc}
\hline $\begin{array}{c}\text { Kombinasi } \\
\text { pembebanan }\end{array}$ & Persamaan \\
\hline Kombinasi & $1,4 \mathrm{DL}$ \\
1 & $1,2 \mathrm{DL}+1,6 \mathrm{LL}$ \\
Kombinasi & \\
2 & \\
Kombinasi & $1,2 \mathrm{DL}+1,6 \mathrm{LL}+1,2 \mathrm{~B}$ \\
3 & \\
Kombinasi & $1,2 \mathrm{DL}+1,6 \mathrm{LL}+1,2 \mathrm{M}$ \\
4 & $0,9 \mathrm{DL}+\mathrm{W}$ \\
Kombinasi & $0,9 \mathrm{DL}+\mathrm{U}$ \\
5 & $1,36 \mathrm{DL}+\mathrm{LL} \pm \mathrm{Ex} \pm$ \\
Kombinasi & $0,3 \mathrm{Ey}$ \\
6 & Ey \\
Kombinasi & $0,3 \mathrm{Ex} \pm$ \\
7 & Ey \\
Kombinasi & $1,36 \mathrm{DL}+\mathrm{LL} \pm 0,3$ \\
8 & $0,74 \mathrm{DL}+\mathrm{LL} \pm \mathrm{Ex}$ \\
Kombinasi & $\mathrm{Ey}$ \\
11 & $0,74 \mathrm{DL}+\mathrm{LL} \pm 0,3 \mathrm{Ex} \pm$ \\
Kombinasi &
\end{tabular}

Hasil running dari pemodelan struktur oleh program SAP2000 yang berupa gaya-gaya dalam dianalisis untuk merencanakan struktur pada balok, kolom, pelat. Analisis struktur akan memberikan output berupa kekuatan dan ketahanan struktur jetty terhadap beban. Analisis struktur juga akan mengetahui penyimpangan yang mungkin terjadi pada struktur dengan jumlah tulangan eksisting setelah dimasukan beban.

\section{HASIL DAN PEMBAHASAN}

\section{Pemodelan Struktur}

Bentuk dermaga yang digunakan pada Pelabuhan Babo Teluk Bintuni adalah bentuk $\mathrm{L}$ sesuai dengan kebutuhan dan kondisi lapangan. Jetty terdiri dari badan jetty untuk melayani kapal saat berlabuh dan trestle sepanjang 48,64 $\mathrm{m}$ yaitu jembatan yang menghubungkan badan jetty dengan daratan. Dermaga dapat disandari dua kapal kecil secara bersamaan. Dermaga yang digunakan berupa jetty dengan denah ditunjukkan pada Gambar 2 dan dimensi seperti ditunjukkan pada Tabel 2.

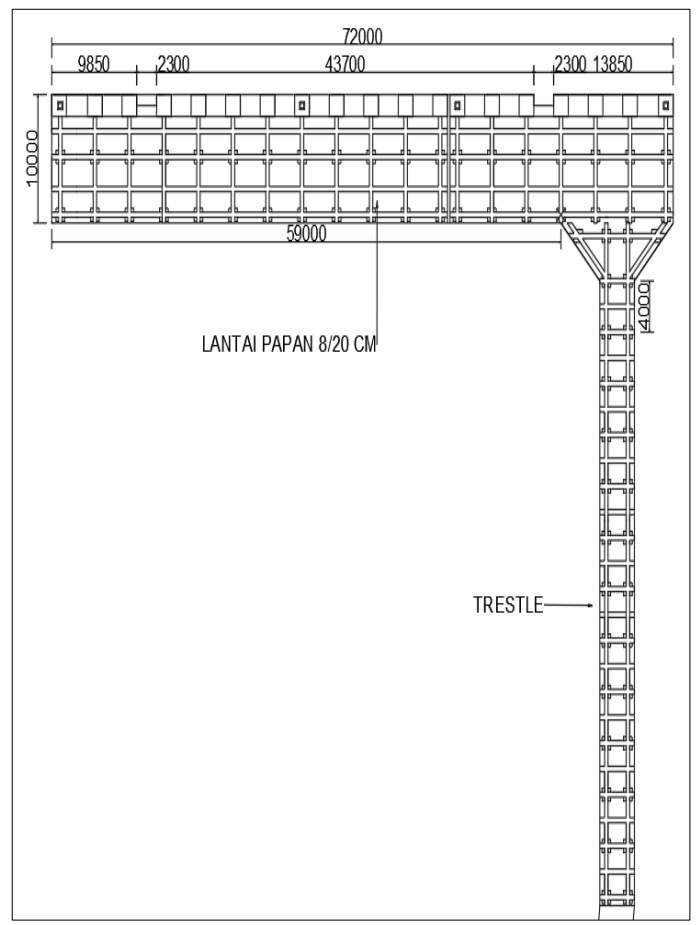

Gambar 2 Denah Struktur Jetty 
Tabel 2 Dimensi Dermaga

\begin{tabular}{lcc}
\hline \multicolumn{1}{c}{ Kriteria } & Ukuran & $\begin{array}{c}\text { Satu } \\
\text { an }\end{array}$ \\
\hline Panjang & 72 & $\mathrm{~m}$ \\
Lebar & 10 & $\mathrm{~m}$ \\
Tebal pelat & 45 & $\mathrm{~cm}$ \\
Balok & $40 \times 60$ & $\mathrm{~cm}$ \\
melintang & $40 \times 50$ & $\mathrm{~cm}$ \\
Balok & $170 \times 50$ & $\mathrm{~cm}$ \\
memanjang & $170 \times 170 \times$ & $\mathrm{cm}$ \\
Balok Fender & 450 & $\mathrm{~cm}$ \\
Pile cap tipe 1 & $100 \times 100 \times$ & \\
Pile cap tipe 2 & 80 & $\mathrm{~cm}$ \\
D tiang & 40 & \\
pancang baja & &
\end{tabular}

Pelat lantai jetty menggunakan kayu mahoni yang merupakan kayu kelas 1. Berat jenis untuk kayu kelas 1 menurut SNI 03-1727-1989 adalah 1000 $\mathrm{Kg} / \mathrm{m}^{3}$. Mutu beton yang digunakan pada bangunan yang dianalisis pada studi ini menggunakan K-350. Tiang pancang sebagai kolom berbahan dasar baja dengan profil baja adalah silinder atau steel pipe $\mathrm{BJ} 50$ diameter $40 \mathrm{~cm}$ dan tebal dinding $1,2 \mathrm{~cm}$. Ketentuan penggunaan pipa baja mengikuti ASTM A252. Penggunaan material dan komponen struktur yang akan digunakan, diinput ke dalam program SAP 2000. Pemodelan 3D menggunakan software SAP 2000 ditunjukkan pada Gambar 3.

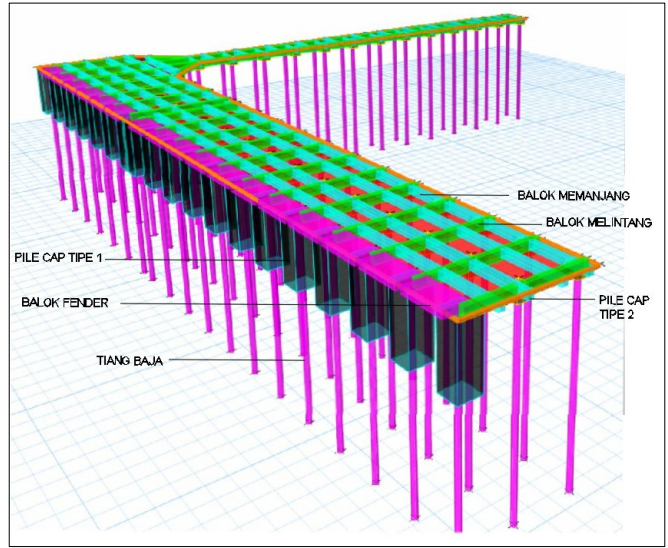

Gambar 3 Pemodelan Struktur Dermaga

\section{Karakteristik Kapal}

Tipe dan bentuk pelabuhan tergantung pada jenis dan karakteristik kapal yang akan berlabuh. Perencanaan pembangunan pelabuhan harus meninjau pengembangan pelabuhan di masa mendatang dengan memperhatikan daerah perairan untuk alur pelayaran, kolam putar, penambatan, dermaga, tempat pembuangan bahan pengerukan, daerah daratan yang diperlukan untuk penempatan, penyimpanan, dan pengangkutan barang-barang (Triatmodjo 2009). Kapal yang akan bertambat pada dermaga jetty Babo memiliki bobot kapal maksimum sebesar 2000 DWT dan merapat di dermaga yang dilindungi sistem fender. Parameter kapal berdasarkan kriteria kapal minyak dan barang pada perencanaan Pelabuhan (Triatmodjo 2009). Karakteristik kapal tersebut ditunjukkan pada Tabel 3.

Tabel 3 Karakteristik Kapal

\begin{tabular}{cccccc}
\hline Bobot kapal & Displacement & Panjang & Breadth & Depth & Draft \\
\hline $\begin{array}{c}\text { DWT } \\
\text { (ton) }\end{array}$ & $\begin{array}{c}\text { W } \\
\text { (ton) }\end{array}$ & $\begin{array}{c}\text { Loa } \\
(\mathrm{m})\end{array}$ & $\begin{array}{c}\text { Lpp } \\
(\mathrm{m})\end{array}$ & $\begin{array}{c}\text { Dkapal } \\
(\mathrm{m})\end{array}$ & $\begin{array}{c}\mathrm{d} \\
(\mathrm{m})\end{array}$ \\
\hline 2000 & 2810 & 73 & 68 & 12,1 & 4,7 \\
\hline
\end{tabular}

Displacement menyatakan berat kapal maksimum, sehingga apabila kapal sudah mencapai displacement tonnage loaded masih dimuati lagi, kapal akan terganggu stabilitasnya sehingga kemungkinan kapal tenggelam menjadi besar. Deadweight Tonnage (DWT) atau bobot mati yaitu berat total muatan saat 
kapal dapat mengangkut dalam keadaan pelayaran optimal (draft maksimum) (Triatmodjo 2009). Loa atau length over all adalah panjang seluruh kapal yang diukur dari bagian paling ujung haluan hingga bagian ujung buritan. Lpp atau length between perpendicular yaitu ukuran kapal yang diukur mulai dari fore peak (FP) hingga after peak (AP), dimana AP merupakan garis tegak lurus pada perpotongan antara LWL dan badan kapal pada bagian buritan dan FP merupakan garis tegak lurus pada perpotongan antara LWL dan badan kapal pada bagian Haluan (Nopandri et al. 2011).

\section{Beban Vertikal}

Pembebanan vertikal pada struktur dermaga dapat dikategorikan dalam beban mati dan beban hidup. Perencanaan dan perhitungan beban vertikal berdasarkan parameter yang ada dalam SNI 1727-2013 tentang "Beban Minimum untuk Perancangan Bangunan Gedung dan Struktur Lain" dan SNI 1725-2016 tentang "Pembebanan untuk Jembatan". Beban hidup pada struktur ini merupakan beban uniformly distributed load (UDL), beban kendaraan, dan beban fasilitas loading/unloading. Gambar 4 menunjukkan truk dengan beban maksimum 14 ton yang dijadikan sebagai beban hidup.

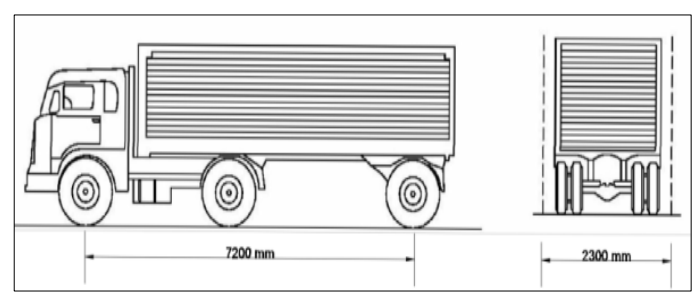

Gambar 4 Ilustrasi Pembebanan Kendaraan
Tabel 4 Beban Vertikal pada Jetty

\begin{tabular}{|c|c|c|}
\hline Kriteria & Nilai & Satuan \\
\hline \multicolumn{3}{|c|}{ Beban mati } \\
\hline $\begin{array}{c}\text { Berat pelat } \\
\text { Berat balok }\end{array}$ & 1,125 & $\mathrm{t} / \mathrm{m}^{2}$ \\
\hline memanjang & 0,5 & $\mathrm{t} / \mathrm{m}$ \\
\hline Berat balok melintang & 0,6 & $\mathrm{t} / \mathrm{m}$ \\
\hline Berat balok fender & 2,125 & $\mathrm{t} / \mathrm{m}$ \\
\hline \multicolumn{3}{|c|}{ Beban hidup } \\
\hline Beban truk angkut & 0,85 & $\mathrm{t} / \mathrm{m}^{2}$ \\
\hline Beban kontainer & 1,04 & $\mathrm{t} / \mathrm{m}^{2}$ \\
\hline Beban tarikan kapal & 17,5 & ton \\
\hline
\end{tabular}

Beban mati terdiri dari berat struktur dan berat peralatan layan tetap. Penentuan beban mati struktur pada pemodelan struktur gedung tidak diberikan seperti pada beban hidup, karena beban mati pada sruktur bangunan yang dimodelkan secara otomatis terhitung ke dalam program SAP 2000.

\section{Beban Horisontal}

Pembebanan horisontal pada struktur dermaga dapat dikategorikan sebagai beban gelombang, beban arus, beban gempa, beban tumbukan kapal, dan gaya tambat.

Respons spektrum adalah suatu spektrum yang disajikan dalam bentuk grafik atau plot antara periode getar struktur $\mathrm{T}$ dengan respon-respon maksimum berdasarkan rasio redaman dan gempa tertentu. Respon-respon maksimum dapat berupa simpangan maksimum (SD), kecepatan maksimum (SV), atau percepatan maksimum (SA). Pelabuhan Babo Teluk Bintuni terletak pada koordinat $2^{\circ} 32^{\prime} 2,07^{\prime \prime}$ LS dan $133^{\circ}$ $27^{\prime} 7,57^{\prime \prime}$ BT. Data desain seismic dan spektrum gempa Pelabuhan Babo ditunjukkan pada Tabel 5 dan Gambar 5.

Data percepatan respon spektrum di lokasi dapat diakses pada website Pusat Penelitian dan Pengembangan Pemukiman (PUSKIM 2020), 
Kementrian Pekerjaan Umum dan Perumahan Rakyat. Berdasarkan spektrum gempa didapatkan nilai parameter respon spektra percepatan desain pada periode pendek $\left(\mathrm{S}_{\mathrm{DS}}\right)$ sebesar 0,8 g. Nilai parameter respon spektra percepatan desain pada periode 1 detik $\left(\mathrm{S}_{\mathrm{D} 1}\right)$ sebesar $0,47 \mathrm{~g}$. Nilai-nilai tersebut diinput ke dalam program SAP 2000 sehingga menghasilkan desain respon spektrum pada Gambar 5 untuk beban gempa.

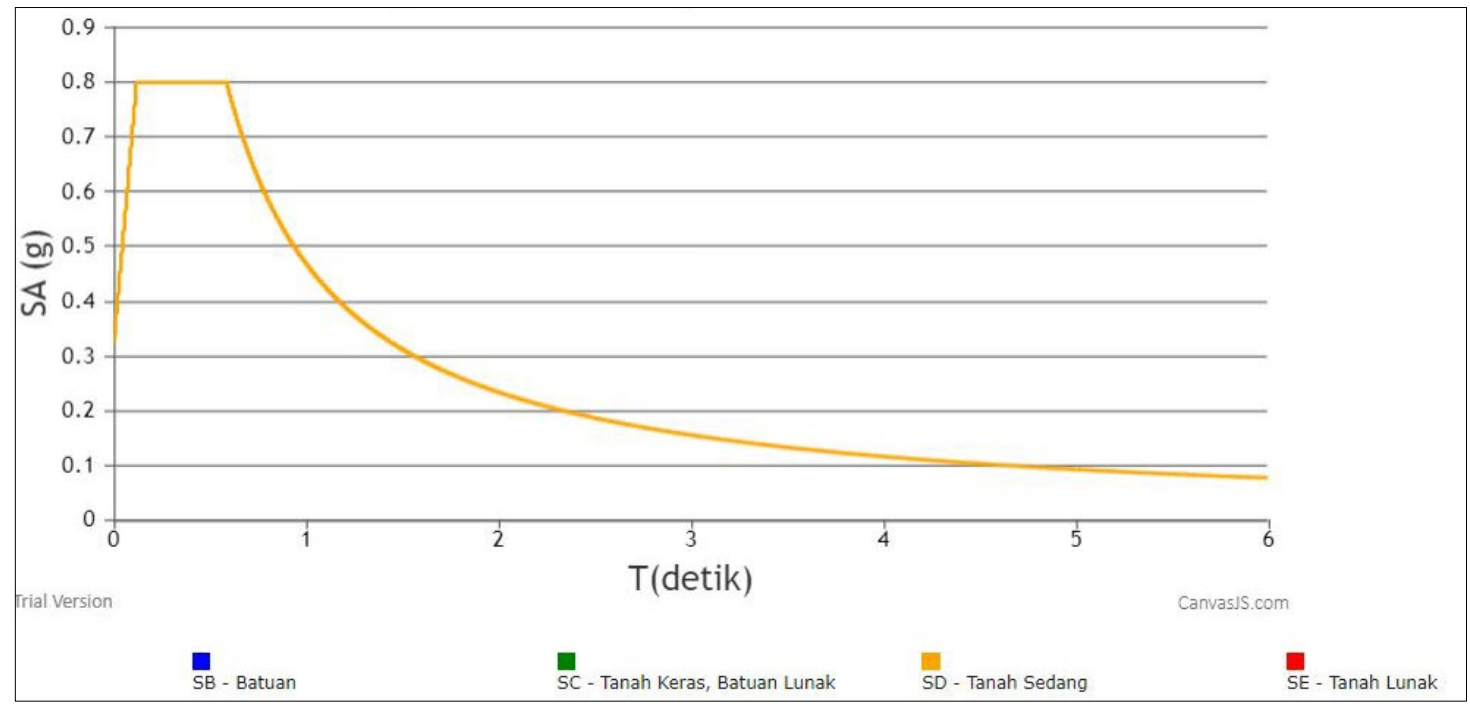

Gambar 5 Spektrum Gempa (PUSKIM 2020)

Tabel 5 Data Seismic Design

\begin{tabular}{lcc}
\hline \multicolumn{1}{c}{ Parameter } & Nilai & Satuan \\
\hline Lokasi & Teluk Bintuni Papua Barat & \\
Kelas Situs & D (Tanah Sedang) & \\
Kategori Resiko & III & \\
Faktor Keutamaan & 1,25 & \\
PGA & 0,5108 & $\mathrm{~g}$ \\
Ss & 1,1577 & $\mathrm{~g}$ \\
S1 & 0,3662 & $\mathrm{~g}$ \\
Fa & 1,1 & $\mathrm{~g}$ \\
Fv & 1,6 & $\mathrm{~g}$ \\
Sms & 1,273 & $\mathrm{~g}$ \\
Sm1 & 0,586 & $\mathrm{~g}$ \\
Sds & 0,8 & $\mathrm{~g}$ \\
Sd1 & 0,47 & $\mathrm{~g}$ \\
KDS & $\mathrm{D}$ & \\
T0 & 0,12 & detik \\
Ts & 0,59 & detik \\
TL & 12 & detik \\
\hline
\end{tabular}

Gaya berthing adalah gaya yang diterima dermaga saat kapal sedang bersandar pada dermaga. Gaya maksimum yang diterima dermaga adalah saat kapal merapat ke dermaga dan membentur dermaga pada sudut $10^{\circ}$ 
terhadap sisi depan dermaga (OCDI 2002). Gaya benturan diterima dermaga dan energinya diserap fender pada dermaga. Ilustrasi gaya sandar kapal dapat dilihat pada Gambar 6. Energi dan gaya benturan terhadap fender ditunjukkan pada Tabel 6 .

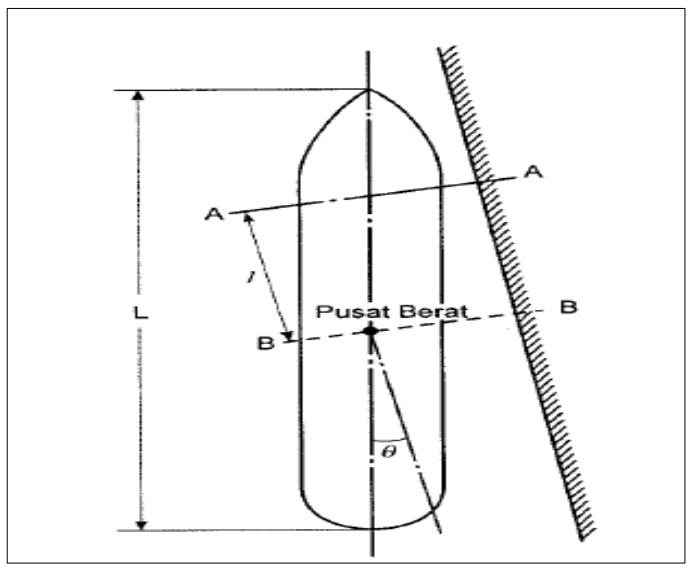

Gambar 6 Ilustrasi Gaya Sandar pada Dermaga (Triatmodjo 2009)

Tabel 6 Gaya Akibat Tumbukan Kapal

\begin{tabular}{llc}
\hline \multicolumn{1}{c}{ Kriteria } & $\begin{array}{l}\text { Ukur } \\
\text { an }\end{array}$ & $\begin{array}{c}\text { Sat } \\
\text { uan }\end{array}$ \\
\hline $\begin{array}{l}\text { Energi benturan kapal } \\
\text { Energi benturan yang }\end{array}$ & 0,89 & tm \\
diserap fender & 0,44 & tm \\
Kapasitas fender & 2,25 & tm \\
Gaya bentur & 7,06 & ton \\
Gaya reaksi fender & 22,50 & ton \\
\hline
\end{tabular}

Fender yang digunakan merupakan fender karet seibu V300H dengan kapasitas fender 2,25 tm dan gaya reaksi fender 22,50 ton (Quinn 1972). Desain fender seibu V ditunjukkan pada Gambar 7. Energi benturan yang diserap fender yaitu 0,44 tm lebih kecil jika dibandingkan dengan kapasitas fender sebesar 2,25, sehingga penggunaan fender memenuhi, sedangkan gaya bentur yang diserap fender sebesar 7,06 ton lebih kecil dari gaya reaksi fender sebesar 22,50 ton sehingga memenuhi kriteria.

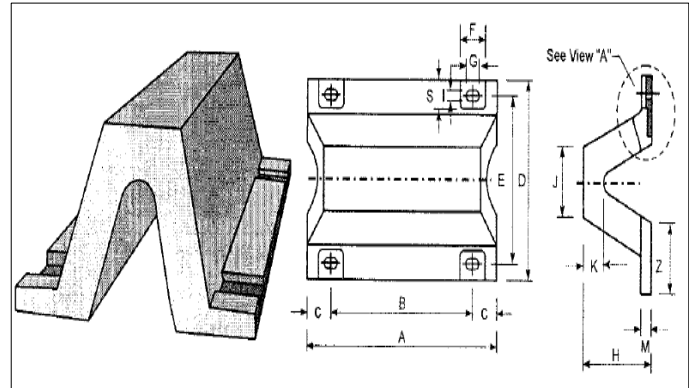

Gambar 7 Desain Fender Seibu V

Kapal yang merapat di dermaga akan ditambatkan dengan menggunakan tali ke alat penambat yang disebut bollard. Pengikatan ini dimaksudkan untuk menahan gerakan kapal yang disebabkan angin dan arus. Bollard ditanam pada dermaga dan harus mampu menahan gaya tarikan kapal. Gaya tambat akibat berbagai arah angin ditunjukkan pada Tabel 7. Hasil perhitungan pembebanan horisontal berdasarkan beberapa standar dan panduan pada struktur jetty ditunjukkan pada Tabel 8.

Tabel 7 Gaya Tambat Akibat Arah Angin

\begin{tabular}{lcc}
\hline \multicolumn{1}{c}{ Kriteria } & Ukuran & Satuan \\
\hline$\alpha=0$ & 0,29 & ton \\
$\alpha=90$ & 4,63 & ton \\
$\alpha=180$ & 0,35 & ton \\
\hline
\end{tabular}

Tabel 8 Rekapitulasi Beban Horisontal

\begin{tabular}{lrc}
\hline \multicolumn{1}{c}{ Kriteria } & Ukuran & Satuan \\
\hline $\begin{array}{l}\text { Beban gelombang pada tiang } \\
\text { Beban gelombang pada tepi }\end{array}$ & 6,80 & ton \\
jetty & 0,30 & $\mathrm{t} / \mathrm{m}$ \\
Gaya drag akibat arus & 0,75 & ton \\
Gaya angkat akibat arus & 1,50 & ton \\
Beban tumbukan kapal & 7,06 & ton \\
Gaya sandar & 4,63 & ton \\
\hline
\end{tabular}




\section{Pemeriksaan Jumlah Ragam}

SNI 03-1726-2012 (BSN 2012) menyebutkan bahwa analisis harus menyatakan jumlah ragam yang cukup untuk mendapatkan partisipasi massa ragam terkombinasi sebesar paling sedikit $90 \%$ dari massa aktual yang dimodelkan. Analisis harus menyertakan jumlah ragam yang cukup dari massa aktual dalam masing-masing arah horizontal dari respon yang ditinjau oleh model. Besarnya partisipasi massa pada pemodelan ini dapat diketahui melalui SAP 2000 pada Tabel 9.

Tabel 9 Nilai Partisipasi Massa

\begin{tabular}{cccc}
\hline Mode & $\begin{array}{c}\text { Periode } \\
\text { detik }\end{array}$ & SumUX & SumUY \\
\hline 1 & 2,212 & 0,000 & 0,000 \\
2 & 2,212 & 0,355 & 0,322 \\
3 & 2,102 & 0,851 & 0,809 \\
4 & 1,911 & 0,985 & 0,985 \\
5 & 0,366 & 0,985 & 0,985 \\
6 & 0,340 & 0,985 & 0,985 \\
7 & 0,211 & 0,985 & 0,985 \\
8 & 0,205 & 0,985 & 0,985 \\
9 & 0,187 & 0,985 & 0,985 \\
10 & 0,187 & 0,985 & 0,985 \\
11 & 0,183 & 0,985 & 0,985 \\
12 & 0,183 & 0,985 & 0,985 \\
\hline
\end{tabular}

Partisipasi massa adalah besarnya rasio partisipasi massa bangunan terhadap getaran yang dialami bangunan. Besarnya partisipasi massa dapat diketahui pada kolom SumUX dan SumUY. Analisis menunjukkan bahwa akselerasi arah $\mathrm{x}$ dan arah y mempunyai ratio modal load participation lebih besar dari 90\%, yang menunjukkan partisipasi massa arah percepatan UX dan UY sudah mencapai $90 \%$ pada mode shape 4. Budiono dan Supriatna (2011) menyebutkan jika jumlah ragam yang sudah ditentukan dalam model belum memenuhi syarat, jumlah ragam perlu ditambahkan hingga memenuhi.

\section{Pemilihan Jenis Ragam}

SNI 03-1726-2012 (BSN 2012) menyebutkan bahwa untuk struktur gedung yang memiliki waktu getar alami yang berdekatan atau selisih nilainya kurang dari 15\% harus dilakukan dengan metoda yang dikenal dengan kombinasi kuadratik lengkap atau complete quadratic combination (CQC). Jika waktu getar alami yang berjauhan, penjumlahan respons ragam tersebut dapat dilakukan dengan metoda akar jumlah kuadrat atau square root of the sum of sguare (SRSS) (BSN 2012). Penentuan tipe analisis ragam respons spektrum yang sesuai melalui selisih dari periode atau waktu getar yang ditunjukkan pada Tabel 10.

Tabel 10 Selisih Periode Setiap Mode

\begin{tabular}{ccc}
\hline Mode & $\begin{array}{c}\text { Periode } \\
(\mathrm{T})\end{array}$ & $\Delta \mathrm{T}$ \\
\hline 1 & 2,212 & 0,000 \\
2 & 2,212 & 4,973 \\
3 & 2,102 & 9,059 \\
4 & 1,911 & 80,875 \\
5 & 0,366 & 7,031 \\
6 & 0,340 & 37,968 \\
7 & 0,211 & 2,721 \\
8 & 0,205 & 9,022 \\
9 & 0,187 & 0,012 \\
10 & 0,187 & 1,770 \\
11 & 0,183 & 0,063 \\
12 & 0,183 & 100,00 \\
\hline
\end{tabular}

Perhitungan selisih periode atau waktu getar dihitung melalui persentase rasio selisih periode awal dan periode setelahnya terhadap periode awal. Berdasarkan perhitungan yang telah dilakukan pada Tabel 11, waktu getar struktur pada mode 4 dan 6 melebihi $15 \%$, sehingga sebaiknya menggunakan kombinasi spektrum SRSS sesuai 
dengan peraturan SNI Gempa pasal 7.2.2. Kombinasi spektrum SRSS kemudian diinput ke dalam program SAP 2000.

\section{Perbandingan Geser Dasar Statis dan Geser Dasar Dinamis}

SNI 03-1726-2012 pasal 7.9.4.1 (BSN 2012) tentang skala gaya menyebutkan bahwa gaya geser dasar dinamis harus lebih besar dari $85 \%$ gaya geser statis. Apabila hal tersebut tidak terpenuhi maka perlu diberikan skala gaya pada model struktur. Pemeriksaan struktur yang dimodelkan berdasarkan ketentuan tersebut ditunjukkan pada Tabel 11.

Tabel 11 menunjukkan persyaratan gaya geser gempa dinamik arah $\mathrm{x}$ dan y belum terpenuhi $\left(\mathrm{V}_{\text {dinamik }}<\right.$ $\mathrm{V}_{\text {statik}}$ ), maka besarnya $\mathrm{V}_{\text {dinamik }}$ harus dikalikan dengan faktor skala. Nilai faktor skala yang dikoreksi diinput ke SAP 2000.

Tabel 11 Hasil Penjumlahan Geser Dasar untuk Masing-masing Gempa

\begin{tabular}{cccccc}
\hline Base shear & $\begin{array}{c}\text { Dinamik } \\
\text { geser dasar } \\
(\mathrm{kN})\end{array}$ & $\begin{array}{c}\text { Statik } \\
\text { geser dasar } \\
(\mathrm{kN})\end{array}$ & $\begin{array}{c}0,85 \mathrm{x} \\
\text { static geser } \\
\text { dasar }(\mathrm{kN})\end{array}$ & $\begin{array}{c}\text { Faktor } \\
\text { skala 0,85 } \\
\text { Vstatik } \\
\text { Vdinamik }\end{array}$ & $\begin{array}{c}\text { Kontrol } \\
\text { Vd }>85 \% \text { Vs }\end{array}$ \\
\hline X - Direction & 854,208 & 2917,728 & 2480,069 & 2,903 & $\begin{array}{c}\text { Tidak } \\
\text { memenuhi } \\
\text { Tidak }\end{array}$ \\
Y - Direction & 846,229 & 2917,728 & 2480,069 & 2,931 & $\begin{array}{c}\text { memenuhi } \\
\text { memenn }\end{array}$ \\
\hline
\end{tabular}

\section{Pemeriksaan Simpangan}

Penentuan simpangan $(\Delta)$ harus dihitung sebagai perbedaan defleksi pada pusat massa di tingkat teratas dan terbawah yang ditinjau. Batas simpangan lantai diatur dalam SNI 03-1726-2012 pasal 7.8.6. Hasil perhitungan simpangan yang terjadi di beberapa titik pada Tabel 12.

Tabel 12 Simpangan Lantai Arah x dan y

\begin{tabular}{lccccccc}
\hline \multicolumn{1}{c}{ Lantai } & $\begin{array}{c}\text { Hsx } \\
(\mathrm{mm})\end{array}$ & $\begin{array}{c}\delta \mathrm{x} \\
(\mathrm{mm})\end{array}$ & $\begin{array}{c}\delta \mathrm{y} \\
(\mathrm{mm})\end{array}$ & $\begin{array}{c}\Delta \mathrm{x} \\
(\mathrm{mm})\end{array}$ & $\begin{array}{c}\Delta \mathrm{y} \\
(\mathrm{mm})\end{array}$ & $\begin{array}{c}\Delta \mathrm{a}(\mathrm{ijin}) \\
(\mathrm{mm})\end{array}$ & Keterangan \\
\hline Pelat titik 355 & 14000 & 64,388 & 67,336 & 283,308 & 296,277 & 350 & Aman \\
Dasar & 0 & 0,000 & 0,000 & 0,000 & 0,000 & 0 & Aman \\
\hline Pelat titik 658 & 14000 & 71,329 & 67,336 & 313,848 & 296,277 & 350 & Aman \\
Dasar & 0 & 0,000 & 0,000 & 0,000 & 0,000 & 0 & Aman \\
\hline
\end{tabular}

Nilai $\delta$ menunjukkan besar defleksi yang terjadi pada struktur arah $\mathrm{x}$ dan y. Nilai tersebut didapatkan dari pemodelan menggunakan SAP 2000 yang kemudian digunakan untuk memperoleh besarnya simpangan yang terjadi pada struktur. Berdasarkan Tabel 13, besar defleksi pada arah $\mathrm{x}$ dan $\mathrm{y}$ masih lebih kecil dari simpangan yang dizinkan, sehingga model struktur memenuhi syarat. Apabila model struktur tidak memenuhi syarat, diperlukan pembesaran dimensi balok dan kolom di beberapa tempat.

\section{Desain Tulangan Lentur}

Struktur beton dipengaruhi oleh keretakan beton, sehingga harus diperhitungkan terhadap kekakuannya. Momen inersia penampang utuh dikalikan dengan persentase efektifitas 
penampang. SNI 2847-2013 (BSN 2013) menyebutkan efektifitas penampang untuk balok adalah 0,35. Faktor ini digunakan pada waktu analisis pendetailan tulangan penampang.
Software SAP 2000 akan menampilkan luas tulangan yang dibutuhkan oleh balok. Tulangan utama balok pada dermaga dan trestle berturut-turut ditunjukkan pada Tabel 13 dan Tabel 14.

Tabel 13 Tulangan Lentur Balok Dermaga

\begin{tabular}{|c|c|c|c|c|c|c|c|c|c|c|c|}
\hline Nama & Ukur & $\begin{array}{l}\mathrm{an} \mathrm{F} \\
\mathrm{mm}\end{array}$ & alok & Daerah & $\begin{array}{c}\text { Letak } \\
\text { tulangan }\end{array}$ & $\begin{array}{c}\text { As perlu } \\
\mathrm{mm} 2\end{array}$ & $\begin{array}{c}\text { As aktual } \\
\text { mm2 }\end{array}$ & Cek & & pas & \\
\hline \multirow{6}{*}{ B1 } & \multirow{6}{*}{400} & \multirow{6}{*}{$x$} & \multirow{6}{*}{500} & \multirow{2}{*}{$\begin{array}{c}\text { Tumpuan } \\
\text { Kiri }\end{array}$} & Atas & 1544 & 1901 & Aman & 5 & $\mathrm{D}$ & 22 \\
\hline & & & & & Bawah & 970 & 1141 & Aman & 3 & $\mathrm{D}$ & 22 \\
\hline & & & & \multirow{2}{*}{ Lapangan } & Atas & 678 & 1141 & Aman & 3 & $\mathrm{D}$ & 22 \\
\hline & & & & & Bawah & 1883 & 1901 & Aman & 5 & $\mathrm{D}$ & 22 \\
\hline & & & & \multirow{2}{*}{$\begin{array}{c}\text { Tumpuan } \\
\text { Kanan }\end{array}$} & Atas & 1535 & 1901 & Aman & 5 & D & 22 \\
\hline & & & & & Bawah & 492 & 1141 & Aman & 3 & D & 22 \\
\hline \multirow{6}{*}{ B2 } & \multirow{6}{*}{400} & \multirow{6}{*}{$\mathrm{x}$} & \multirow{6}{*}{600} & \multirow{2}{*}{$\begin{array}{c}\text { Tumpuan } \\
\text { Kiri }\end{array}$} & Atas & 2194 & 2455 & Aman & 5 & D & 25 \\
\hline & & & & & Bawah & 1058 & 1473 & Aman & 3 & D & 25 \\
\hline & & & & \multirow{2}{*}{ Lapangan } & Atas & 694 & 1473 & Aman & 3 & $\mathrm{D}$ & 25 \\
\hline & & & & & Bawah & 2027 & 2455 & Aman & 5 & D & 25 \\
\hline & & & & \multirow{2}{*}{$\begin{array}{c}\text { Tumpuan } \\
\text { Kanan }\end{array}$} & Atas & 1560 & 1964 & Aman & 4 & D & 25 \\
\hline & & & & & Bawah & 3950 & 4420 & Aman & 9 & D & 25 \\
\hline \multirow{6}{*}{ B3 } & \multirow{6}{*}{1700} & \multirow{6}{*}{$\mathrm{x}$} & \multirow{6}{*}{500} & \multirow{2}{*}{$\begin{array}{c}\text { Tumpuan } \\
\text { Kiri }\end{array}$} & Atas & 1554 & 1901 & Aman & 5 & $\mathrm{D}$ & 22 \\
\hline & & & & & Bawah & 773 & 1141 & Aman & 3 & $\mathrm{D}$ & 22 \\
\hline & & & & \multirow{2}{*}{ Lapangan } & Atas & 489 & 1141 & Aman & 3 & $\mathrm{D}$ & 22 \\
\hline & & & & & Bawah & 555 & 1141 & Aman & 3 & $\mathrm{D}$ & 22 \\
\hline & & & & \multirow{2}{*}{$\begin{array}{c}\text { Tumpuan } \\
\text { Kanan }\end{array}$} & Atas & 386 & 1141 & Aman & 3 & $\mathrm{D}$ & 22 \\
\hline & & & & & Bawah & 960 & 1141 & Aman & 3 & $\mathrm{D}$ & 22 \\
\hline
\end{tabular}

Tabel 14 Tulangan Lentur Balok Trestle

\begin{tabular}{|c|c|c|c|c|c|c|c|c|c|c|c|}
\hline Nama & Uku & n $\mathrm{B}$ & lok & Daerah & $\begin{array}{l}\text { Letak } \\
\text { tulangan }\end{array}$ & $\begin{array}{c}\text { As } \\
\text { perlu } \\
\text { mm2 }\end{array}$ & $\begin{array}{c}\text { As } \\
\text { aktual } \\
\text { mm2 }\end{array}$ & Cek & & pas & \\
\hline \multirow{6}{*}{ B1 } & \multirow{6}{*}{400} & \multirow{6}{*}{$\mathrm{x}$} & \multirow{6}{*}{500} & Tumpuan & Atas & 1894 & 1901 & Aman & 5 & $\mathrm{D}$ & 22 \\
\hline & & & & Kiri & Bawah & 146 & 1141 & Aman & 3 & $\mathrm{D}$ & 22 \\
\hline & & & & & Atas & 337 & 1141 & Aman & 3 & $\mathrm{D}$ & 22 \\
\hline & & & & Lapangan & Bawah & 645 & 1141 & Aman & 3 & $\mathrm{D}$ & 22 \\
\hline & & & & Tumpuan & Atas & 115 & 1141 & Aman & 3 & $\mathrm{D}$ & 22 \\
\hline & & & & Kanan & Bawah & 299 & 1141 & Aman & 3 & $\mathrm{D}$ & 22 \\
\hline \multirow{6}{*}{ B2 } & \multirow{6}{*}{400} & \multirow{6}{*}{$\mathrm{x}$} & \multirow{6}{*}{600} & Tumpuan & Atas & 825 & 1141 & Aman & 3 & $\mathrm{D}$ & 22 \\
\hline & & & & Kiri & Bawah & 825 & 1521 & Aman & 4 & $\mathrm{D}$ & 22 \\
\hline & & & & & Atas & 1807 & 1901 & Aman & 5 & $\mathrm{D}$ & 22 \\
\hline & & & & Lapangan & Bawah & 825 & 1521 & Aman & 4 & $\mathrm{D}$ & 22 \\
\hline & & & & Tumpuan & Atas & 2860 & 3042 & Aman & 8 & $\mathrm{D}$ & 22 \\
\hline & & & & Kanan & Bawah & 1363 & 1521 & Aman & 4 & $\mathrm{D}$ & 22 \\
\hline
\end{tabular}

Balok B1, B2, dan B3 berturutturut merupakan balok memanjang, balok melintang, dan balok fender. Luas tulangan perlu merupakan output yang dihasilkan dari perhitungan menggunakan SAP 2000. Penggunaan tulangan akan aman apabila luas tulangan perlu lebih kecil dibandingkan luas tulangan aktual. 
Tabel 14 menunjukkan jumlah tulangan utama pada struktur trestle. Terdapat 2 jenis balok pada struktur trestle yaitu, B1 untuk balok memanjang dan B2 untuk balok melintang. Tulangan utama pada balok trestle menggunakan tulangan berdiameter $22 \mathrm{~mm}$, dengan jumlah tulangan memenuhi luas tulangan yang diperlukan.

Tabel 15 Tulangan Geser Balok Dermaga

\begin{tabular}{|c|c|c|c|c|c|c|c|c|c|c|}
\hline \multirow[t]{2}{*}{ Nama } & \multicolumn{3}{|c|}{$\begin{array}{c}\text { Ukuran Balok } \\
\mathrm{mm}\end{array}$} & \multirow{2}{*}{$\begin{array}{c}\text { Daerah } \\
\text { Tumpuan Kiri }\end{array}$} & \multirow{2}{*}{$\begin{array}{c}\begin{array}{c}\text { Sperlu } \\
\text { mm }\end{array} \\
54,37\end{array}$} & \multirow{2}{*}{$\begin{array}{c}\begin{array}{c}\text { Smax } \\
\text { mm }\end{array} \\
110\end{array}$} & \multirow{2}{*}{$\begin{array}{c}\begin{array}{c}\text { Sterpakai } \\
\text { mm }\end{array} \\
54,37\end{array}$} & \multicolumn{3}{|c|}{ Dipasang } \\
\hline & & & & & & & & $\mathrm{P}$ & 10 & 50 \\
\hline \multirow[t]{3}{*}{ B1 } & 400 & $\mathrm{x}$ & 500 & Lapangan & 42,83 & 220 & 42,83 & $\mathrm{P}$ & 10 & 40 \\
\hline & & & & $\begin{array}{c}\text { Tumpuan } \\
\text { Kanan }\end{array}$ & 42,46 & 110 & 42,46 & $\mathrm{P}$ & 10 & 40 \\
\hline & & & & Tumpuan Kiri & 49,02 & 134 & 49,02 & $\mathrm{P}$ & 10 & 40 \\
\hline \multirow[t]{3}{*}{ B2 } & 400 & $\mathrm{x}$ & 600 & Lapangan & 83,10 & 269 & 83,10 & $\mathrm{P}$ & 10 & 80 \\
\hline & & & & $\begin{array}{c}\text { Tumpuan } \\
\text { Kanan }\end{array}$ & 96,58 & 134 & 96,58 & $\mathrm{P}$ & 10 & 90 \\
\hline & & & & Tumpuan Kiri & 55,63 & 110 & 55,63 & $\mathrm{P}$ & 10 & 50 \\
\hline \multirow[t]{2}{*}{ BB3 } & 1700 & $\mathrm{x}$ & 500 & Lapangan & 60,21 & 220 & 60,21 & $\mathrm{P}$ & 10 & 60 \\
\hline & & & & $\begin{array}{c}\text { Tumpuan } \\
\text { Kanan }\end{array}$ & 60,21 & 110 & 60,21 & $\mathrm{P}$ & 10 & 60 \\
\hline
\end{tabular}

Tabel 16 Tulangan Geser Balok Trestle

\begin{tabular}{|c|c|c|c|c|c|c|c|c|c|c|}
\hline Nama & Ukur & $\begin{array}{l}\mathrm{an} \mathrm{I} \\
\mathrm{mm}\end{array}$ & 3alok & Daerah & Sperlu mm & Smax mm & Sterpakai mm & \multicolumn{3}{|c|}{ Dipasang } \\
\hline \multirow{3}{*}{ B1 } & \multirow{3}{*}{400} & \multirow{3}{*}{$\mathrm{x}$} & \multirow{3}{*}{500} & Tumpuan Kiri & 39,78 & 110 & 39,78 & $\mathrm{P}$ & 10 & 30 \\
\hline & & & & Lapangan & 40,36 & 220 & 40,36 & $\mathrm{P}$ & 10 & 40 \\
\hline & & & & Tumpuan Kanan & 1106,64 & 110 & 109,75 & $\mathrm{P}$ & 10 & 100 \\
\hline \multirow{3}{*}{ B2 } & \multirow{3}{*}{400} & \multirow{3}{*}{$\mathrm{x}$} & \multirow{3}{*}{600} & Tumpuan Kiri & 29,82 & 132 & 29,82 & $\mathrm{P}$ & 10 & 20 \\
\hline & & & & Lapangan & 49,60 & 270 & 49,60 & $\mathrm{P}$ & 10 & 40 \\
\hline & & & & Tumpuan Kanan & 48,28 & 132 & 48,28 & $\mathrm{P}$ & 10 & 40 \\
\hline
\end{tabular}

\section{Desain Tulangan Geser (Sengkang)}

Luas tulangan geser yang dihasilkan pada SAP 2000 menunjukkan kebutuhan luas tulangan sengkang. Hasil perhitungan jumlah tulangan sengkang pada dermaga ditunjukkan pada Tabel 15. Rekaptulasi kebutuhan tulangan geser balok pada trestle ditunjukkan pada Tabel 16.

Tulangan geser yang dipasang pada sendi plastis (daerah tumpuan) harus memenuhi persyaratan SNI beton 2847 : 2013 Pasal 21.5.3.2, sedangkan untuk diluar sendi plastis (daerah lapangan) harus memenuhi persyaratan 
pasal 21.5.3.4. Balok B1 dan B2 memerlukan tulangan sengkang menggunakan tulangan polos berdiameter $10 \mathrm{~mm}$. Tumpuan kiri, lapangan, dan tumpuan kanan berturutturut pada B1 memiliki jarak sengkang sebesar $50 \mathrm{~mm}, 40 \mathrm{~mm}$, dan $40 \mathrm{~mm}$.

\section{Desain Tulangan Torsi}

Detail dari tulangan torsi pada balok B1 ditunjukkan pada Gambar 8 .

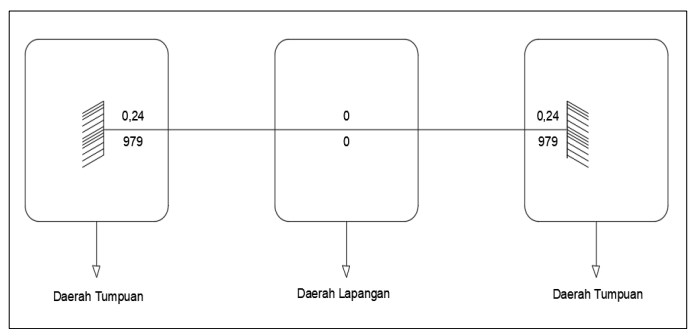

Gambar 8 Tulangan Torsi Balok B1

Berdasarkan gambar B1, nilai bagian atas menunjukkan luas tulangan torsi untuk sengkang dan bagian bawah menunjukkan luas tulangan torsi untuk tulangan utama (atas dan bawah). Karena luas tulangan torsi lebih kecil, sehingga cukup dipasang tulangan D16 dikedua sisinya.

\section{Detail Tulangan Balok}

Detail penulangan balok B1 pada dermaga ditunjukkan pada Gambar 9, sedangkan detail penulangan balok B1 pada trestle ditunjukkan pada Gambar 10.

Tulangan balok yang didesain merupakan output dari porgram SAP 2000. Desain struktur pada Gambar 22 dan Gambar 23 merupakan desain yang aman terhadap beban yang bekerja. Desain tersebut tidak dapat dibandingkan dengan kondisi eksisting karena waktu saat penelitian dalam keadaan pandemi COVID-19. Sehingga diperlukannya evaluasi apakah memenuhi eksisting atau tidaknya.

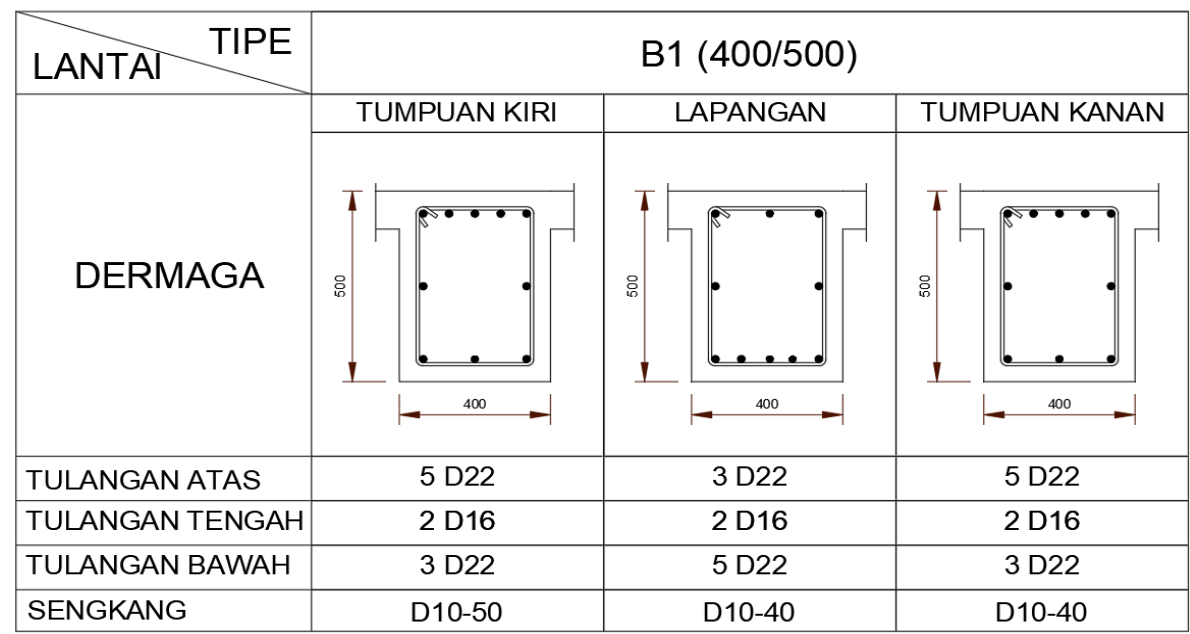

Gambar 9 Detail Penulangan Balok B1 Dermaga 


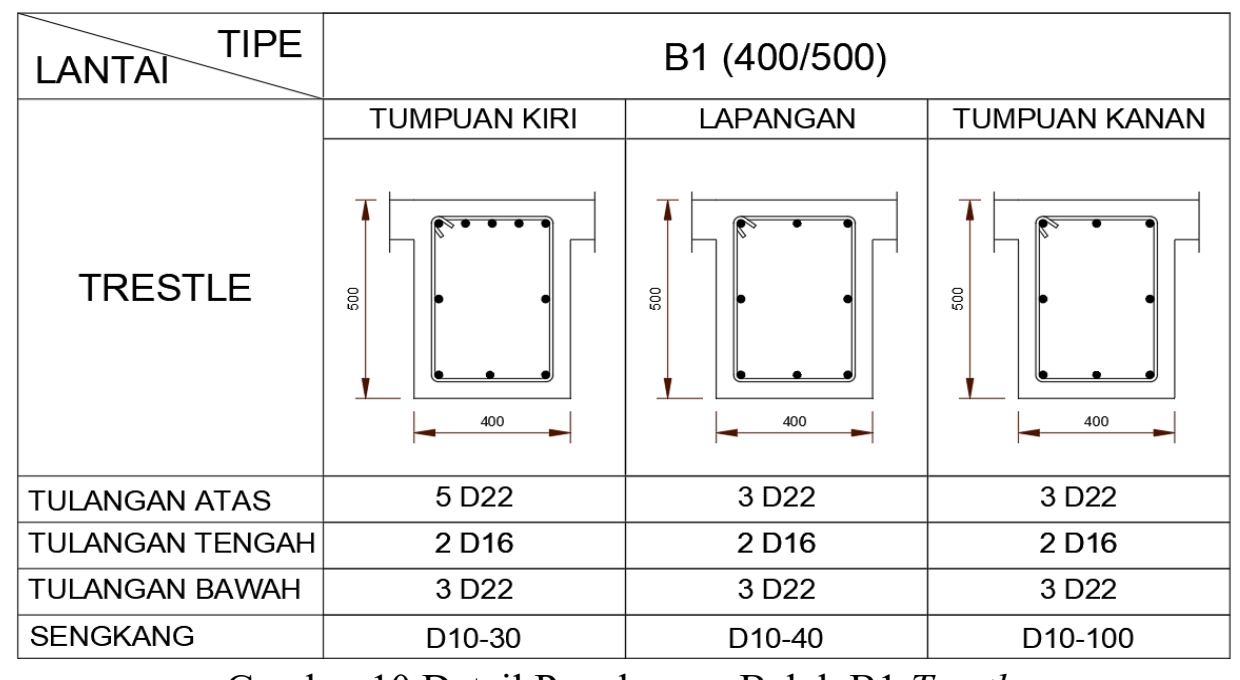

Gambar 10 Detail Penulangan Balok B1 Trestle

\section{Pondasi Dermaga}

Pondasi yang digunakan adalah pondasi tiang pancang baja dengan diameter luar $400 \mathrm{~mm}$ dan tebal $12 \mathrm{~mm}$. Analisis tegangan menghasilkan nilai stress ratio yang muncul pada tiang pancang. Analisis tegangan tiang pancang baja ditunjukkan pada Tabel 17.

Hasil stress ratio maksimum yang diperoleh pada struktur dermaga adalah 0,940, nilai tersebut mendekati 1 , sehingga memenuhi kapasitasnya. Sedangkan nilai stress ratio pada struktur trestle adalah 0,078. Nilai tersebut masih kurang dari kapasitas tiang, sehingga aman. Namun apabila menggunakan tiang baja berdiameter $400 \mathrm{~mm}$, pemakaian tiang lebih boros karena kapasitasnya terlalu besar, sehingga perlu evaluasi dimensi tiang. Berdasarkan perhitungan menggunakan SAP 2000, diperlukan tiang pancang baja untuk struktur trestle dengan diameter $300 \mathrm{~mm}$ dan tebal $12 \mathrm{~mm}$. Stress ratio yang dihasilkan adalah 0,286 dan memenuhi kapasitasnya.

Tabel 17 Analisis Tegangan Tiang

\begin{tabular}{ccccc}
\hline Tiang Baja & $\begin{array}{c}\text { Diameter } \\
\mathrm{mm}\end{array}$ & $\begin{array}{c}\text { Ketebalan } \\
\mathrm{mm}\end{array}$ & $\begin{array}{c}\text { Stress } \\
\text { ratio }\end{array}$ & Keterangan \\
\hline Dermaga & 400 & 12 & 0,940 & Aman \\
Trestle & 400 & 12 & 0,078 & Boros \\
Trestle & 300 & 12 & 0,286 & Aman \\
\hline
\end{tabular}

\section{KESIMPULAN}

Perhitungan pembebanan pada struktur jetty meliputi beban mati, beban hidup, beban gelombang, beban arus, beban sandar kapal, beban tambat kapal, dan beban gempa menunjukkan bahwa jetty memiliki kekuatan cukup untuk menahan beban dengan diperlukannya penggunaan fender karet seibu $\mathrm{V} 300 \mathrm{H}$ untuk meredam beban.

Hasil analisis menunjukkan tidak terjadinya penyimpangan terhadap struktur karena komponen elemen yang dirancang memenuhi desain yang aman terhadap beban yang bekerja. Desain kondisi eksisting tidak dapat dibandingkan dengan desain aman, karena kondisi pandemi COVID-19. 
Ketahanan struktur jetty memenuhi persyaratan SNI 2847-2013 dan SNI 1726-2012. Keseluruhan elemen pada struktur jetty sanggup menahan beban yang bekerja. Penggunaan tiang pancang baja pada trestle dinilai kurang tepat, karena kapasitas tiang terlalu besar

\section{DAFTAR PUSTAKA}

[BSN] Badan Standardisasi Nasional. 2012. Tata Cara Perencanaan Ketahanan Gempa untuk Struktur Bangunan Gedung dan Non Gedung, SNI 1726-2012. Jakarta (ID): Badan Standardisasi Nasional.

[BSN] Badan Standardisasi Nasional. 2013. Persyaratan Beton Struktural untuk Bangunan Gedung, SNI 2847-2013. Jakarta (ID): Badan Standardisasi Nasional.

Budiono B, Supriatna L. 2011. Studi Komparasi Desain Bangunan Tahan Gempa dengan Menggunakan SNI 03-1726-2002 dan RSNI 03-1726-201X. Bandung (ID): ITB Press

[DepKP] Departemen Kelautan dan Perikanan. 2004. Undang-undang RI No. 31 tahun 2004 Tentang Perikanan. Jakarta (ID): Departemen Kelautan dan Perikanan.

Nopandri R, Fauziyah, Rozirwan. 2011. Stabilitas statis kapal bottom gillnet di Pelabuhan Perikanan Nusantara Sungailiat Bangka Belitung. Maspari Journal. 2(1): 63-69.

Nusantara MA. 2014. Analisa daya dukung pondasi dangkal pada tanah lempung menggunakan perkuatan anyaman bambu dan grid bambu dengan bantuan program plaxis. Jurnal Teknik
Sipil dan Lingkungan. 2(3): 364372

[OCDI] The Overseas Coastal Area Development Institute of Japan. 2002. Technical Standards and Commentaries for Port and Harbour Facilities in Japan. Tokyo (JP): Japan Ports and Harbours Association.

[POLB] Port Of Long Beach. 2012. Port of Long Beach Wharf Design Criteria. California (US): Port of Long Beach.

[PUSKIM] Pusat Penelitian dan Pengembangan Perumahan dan Pemukiman. 2020. Desain Spektra Indonesia.

http://rsapuskim2019.litbang.pu.g o.id. (26 Juli 2020).

Quinn AD. 1972. Design and Constraction of Port and Marine Structure. New York (US): Mc Graw-Hill Book Company.

Triatmodjo B. 2009. Perencanaan Pelabuhan. Yogyakarta (ID): Beta Offset. 